\title{
Diagnosis and management of symptomatic residual ureteral stump after nephrectomy
}

\author{
Sohrab Arora, ${ }^{1,2}$ Priyank Yadav, ${ }^{1}$ Mohammad S Ansari ${ }^{1}$
}

${ }^{1}$ Department of Urology and Renal Transplant, Sanjay Gandhi Postgraduate Institute of Medical Sciences, Lucknow, Uttar Pradesh, India

${ }^{2}$ Department of Urology and Renal Transplantation, Sanjay Gandhi Postgraduate Institute of Medical Sciences, Patiala, Punjab, India

\section{Correspondence to} Dr Sohrab Arora, sohrab.arora@gmail.com

Accepted 5 February 2015

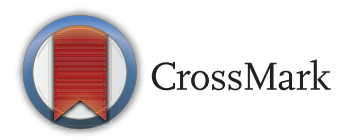

To cite: Arora S, Yadav P, Ansari MS. BMJ Case Rep Published online: [please include Day Month Year] doi:10.1136/bcr-2015209441

\section{DESCRIPTION}

An 8-year-old boy presented with a history of open nephrectomy 1 year prior for non-functioning right kidney with recurrent febrile urinary tract infection (UTI) with bilateral vesicoureteric reflux (VUR) (right grade V and left grade IV). One month after surgery, he did not have any episodes of febrile urinary tract infection but had recurrent right abdominal pain. He had a good urinary stream and no evidence of voiding dysfunction. $\mathrm{He}$ was managed conservatively with antibiotics and analgesics but the episodes of pain recurred. He had no fever. Cystogram was performed under culturebased antibiotic cover, which revealed high-grade reflux in the redundant residual ureteric stump along with left VUR. Figure 1 shows the filling phase of the cystogram and figure 2 shows the voiding cystourethrogram. A diagnosis of recurrent stumpitis was made and the child underwent right laparoscopic stumpectomy with left deflux injection. The child is now asymptomatic at 6 months of follow-up with no right flank pain.

Ureteral stumps left after nephrectomy for primary vesicoureteral reflux, even though high grade, present a low rate of complications. ${ }^{1}$ Most remain asymptomatic, although recurrent bacteriuria, haematuria, stones and even malignancy are known. Owing to the low incidence of complications associated with a refluxing ureteral stump, nephrectomy and proximal ureterectomy has been

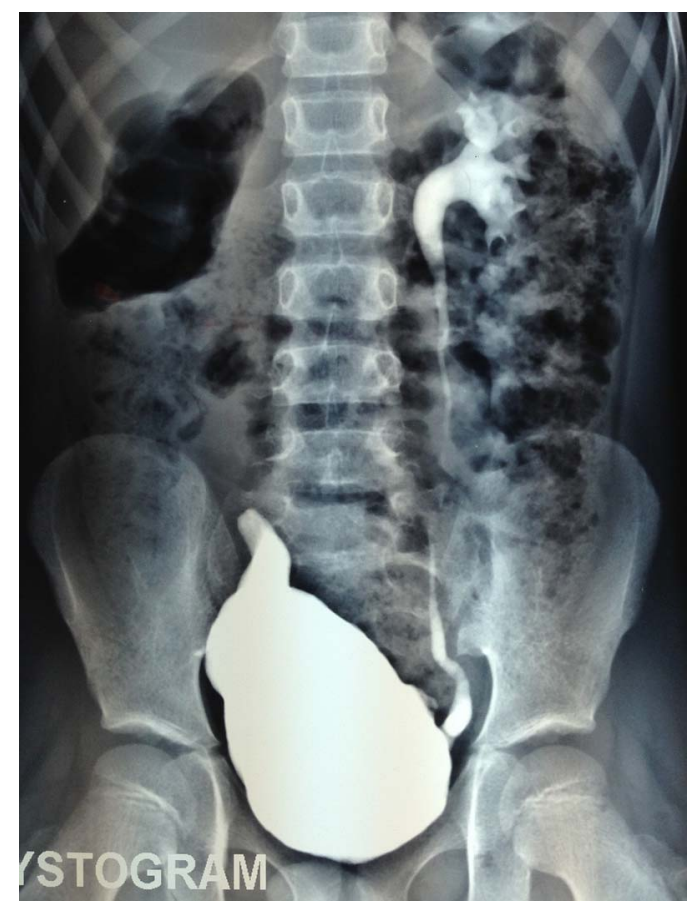

Figure 1 Filling cystogram.

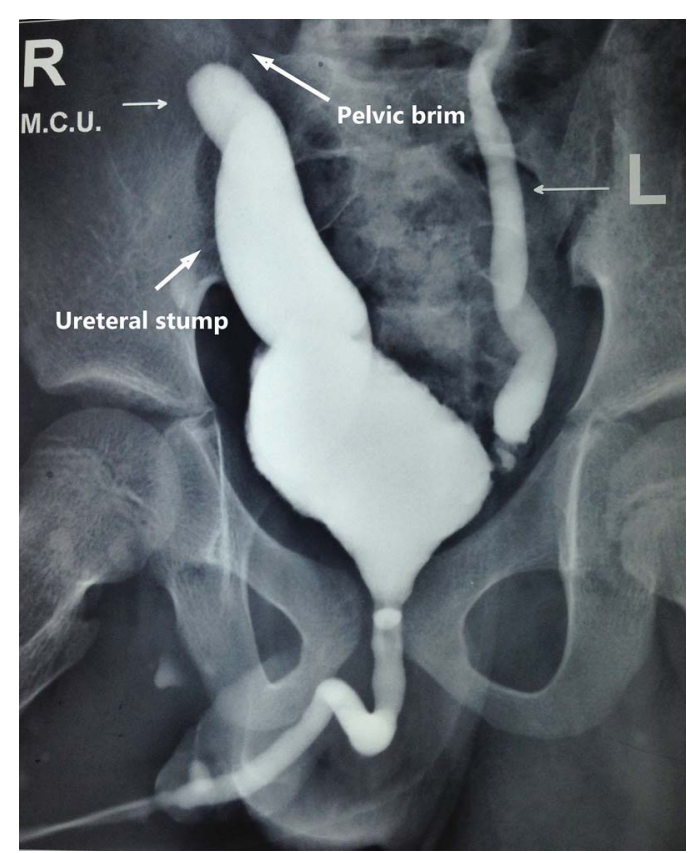

Figure 2 Voiding cystourethrogram.

recommended as the standard procedure for reflux into a non-functioning kidney. ${ }^{2}$ If a symptomatic ureteral remnant is present, then distal ureterectomy decreases the rate of symptomatic UTIs in these patients. ${ }^{3}$

\section{Learning points}

- Nephrectomy and proximal ureterectomy is recommended as the standard procedure for reflux into a non-functioning kidney.

- Incidence of symptomatic ureteral stump after nephrectomy for high-grade vesicoureteric reflux is low.

- In rare cases, the residual stump is symptomatic, and excision of the stump is curative.

Twitter Follow sohrab arora at @drsohrab

Competing interests None.

Patient consent Obtained.

Provenance and peer review Not commissioned; externally peer reviewed.

\section{REFERENCES}

1 Barroso $U$ Jr, Calado AA, Filho MZ. The role of refluxing distal ureteral stumps after nephrectomy. Braz J Urol 2001;27:478-82. 
2 Cain MP, Pope JC, Casale AJ, et al. Natural history of refluxing distal ureteral stumps after nephrectomy and partial ureterectomy for vesicoureteral reflux. J Urol 1998;160:1026-7.
3 Casale P, Grady RW, Lee RS, et al. Symptomatic refluxing distal ureteral stumps after nephroureterectomy and heminephroureterectomy. What should we do? I Urol 2005;173:204-6.

Copyright 2015 BMJ Publishing Group. All rights reserved. For permission to reuse any of this content visit http://group.bmj.com/group/rights-licensing/permissions.

BMJ Case Report Fellows may re-use this article for personal use and teaching without any further permission.

Become a Fellow of BMJ Case Reports today and you can:

- Submit as many cases as you like

- Enjoy fast sympathetic peer review and rapid publication of accepted articles

- Access all the published articles

- Re-use any of the published material for personal use and teaching without further permission

For information on Institutional Fellowships contact consortiasales@bmjgroup.com

Visit casereports.bmj.com for more articles like this and to become a Fellow 